\title{
Analysis and Measurement of Scientific Collaboration Networks Performance
}

\author{
Imam Much Ibnu Subroto ${ }^{1}$, Sam Farisa Chaerul Haviana ${ }^{2}$, Wiwiek Fatmawati ${ }^{3}$ \\ ${ }^{1,3}$ Department of Informatics, Universitas Islam Sultan Agung, Semarang \\ ${ }^{2}$ Department of Industrial Engineering, Universitas Islam Sultan Agung, Indonesia
}

\begin{abstract}
Article Info
Article historys:

Received Jun 9, 2019

Revised Nov 20, 2019

Accepted Dec 11, 2019

\section{Keywords: \\ Research Collaboration \\ Performance Score \\ Research University}

SINTA

ABSTRACT

Collaboration of scientific research among researchers or universities is very important specially to improve the quality and quantity of the research. It gives the positive impact and very beneficial for both parties so this scientific research network becomes an important component in measuring performance and ranking institutions for national and international levels. The interviews result show that the amount of collaboration alone cannot fair to be used as performance measurement, because in general the successful collaboration can be established to other institutions with higher ranks, which will give a good quality impact to the institution. The purpose of this paper is to propose a new performance measurement formula using case studies in Indonesia. Scientific collaboration networks are generated based on data from lecturers and institutions, especially research outputs indexed in the SINTA (Science and Technological Index). SINTA is the largest and most comprehensive portal for measuring research performance in Indonesia. The formula proposed in this research is to consider the number and weighting based on the score of the institution in the previous year to calculate a new score of the performance of the scientific collaboration network. Implementation results show that Riau Province has the highest collaboration score at the regional level, while the Bandung Institute of Technology as an institution with a score of 48,656 is the highest at the institutional level.
\end{abstract}

Copyright (C) 2020 Institute of Advanced Engineering and Science. All rights reserved.

\section{Corresponding Author:}

Imam Much Ibnu Subroto, Department of Informatics, Universitas Islam Sultan Agung,

Jalan Kaligawe Km 4 Semarang, Central Java, Indonesia

Email: imam@unissula.ac.id

\section{INTRODUCTION}

Higher education is a place where knowledge grows due to learning activities and research activities which are of a higher level than scientific activities in previous schools. Each university has lecturers and research resources that are important in the development of science that has an impact on the progress of a nation. The resources and fields of specialization of tertiary institutions are different, even some universities have their own uniqueness which is different from other institutions. Previous research conducted by Aldieri et.al. [1] showed that the connection between universities with different relevance to collaborate with each other will improve the quality of research for both parties. Therefore, collaboration can be one of the supporting parameters for measuring the quality of higher education.

Referring to the positive impact of collaboration, the question will arise how to measure the collaboration performance of a university. Whether the number of publications alone is sufficient as a benchmark and whether every collaboration with a university will have the same impact on research when compared to collaborations with other campuses. If the impact cannot be considered the same, it requires a formula that can accommodate the problem so that the measurement can be fairer. This research proposes a new collaboration measurement standard that gives different weight to each collaboration. Collaboration with 
higher level institutions will have a greater impact than collaboration with lower level institutions. This study measures the performance of all tertiary institutions in Indonesia, which number around 4634 universities as a case study and the implementation of this collaboration measurement. Each university can collaborate with many other universities to form a network so that further this research uses the term Scientific Collaboration Networks Performance.

Previous research has been conducted by Aldieri [1] to analyze and investigate the performance of research collaborations conducted by researchers and institutions in Italy. Cooperation map based on regional performance is analyzed with representative. The results show that international cooperation has a greater impact on institutions. Several researchers conducted a collaborative bibliometric analysis such as that conducted by Nagpaul [2] for the case of co-publication among the top 45 countries in terms of publication activities; Paier and Scherngell [3] for the case of collaborative research between organizations in European countries in the European Framework Program for Research and Technology Development (EU-FPs); Kuld [4] for thematic closeness analysis on citations for a sample of the 1000 most cited economists.

Research collaborations have also been discussed by several researchers to support the development of university research capacity such as Stein et al.[5]; Graue et al.[6]; Kodama et al.[7] ; Riahi et al.[8]; Sweileh et al. [9]). Research collaborations are needed to increase the productivity of general research in universities [see for example: Beaudry and Allaoui [10]; Lissoni et al.[11]; Zucker and Darby[12]; Elhorst and Zigova [13]; Chakravarty and Madaan[14]). Scientific collaboration with developed countries helps universities from less developed countries to improve their research capacity and performance (see here Obamba and Mwema [15]; Chinchilla-Rodríguez et al.[16].

\section{RESEARCH METHOD}

This research attempted to involve all universities in Indonesia, totaling 4634 universities. The SINTA Science and Technology Index has recorded research and publication activities carried out by each research study at universities in Indonesia. The study used all data held by the SINTA database to measure the performance of higher education research networks throughout Indonesia.

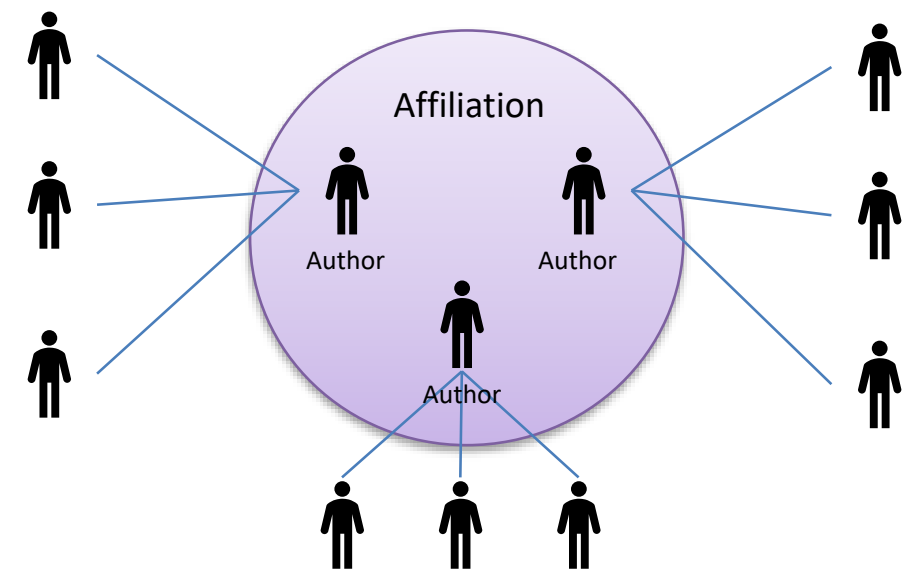

Fig 1 Author Collaboration Network of an Affiliation

The development of a collaboration network begins with collecting research collaboration networks carried out by researchers who have collaborated with other institutions. Research collaboration can be seen from the collaboration of publications in reputable journals or proceedings which in this study use coauthorship of publications indexed on Scopus. This collection of collaboration between individual authors then forms a collaborative network between higher education institutions. The characteristics of this collaboration network will be different for each institution so it is interesting to analyze and measure the collaboration index at each institution.

\subsection{Data Collection}

The main data source comes from the SINTA database, which is the largest author and affiliation indexation system in Indonesia built by the government, namely the Research and Technology and Higher Education Commission in 2017. In SINTA, there is university profile data and college performance scores based on published research outputs [17]. Performance measures are calculated with a 3-year window and overalls. 


\subsection{Model of Collaboration Network Performance}

This research has conducted a study on how to measure collaboration performance, especially at the institutional level. By using publication data in Scopus and institutional performance matrices in SINTA, the proposed parameters to measure collaboration performance in this study are:

a. Number of publication collaborations between institutions

Publication collaboration means a scientific work in a reputable international publication that is coauthored by several researchers with different affiliations. In this model, only reputable international publications (indexed by Scopus) are included because of quality considerations.

b. Number of collaborating institutions

Collaboration with only one institution will certainly have different values when compared to collaboration with many institutions. Collaboration with many institutions will have more value than collaboration with few institutions

c. Collaborating institution weight

Collaborating with other institutions with better performance will be more profitable because it will improve the quality of publications. Institutional weights are given for each institution based on the Sinta Score in the previous period. This weight will be the multiplier of each publication co-authored between the two institutions. In this study, tertiary institutions were divided into 4 clusters based on the SINTA score in the last 3 years as shown in Table 1.

Table 1. The weight of research collaboration between universities

\begin{tabular}{cc}
\hline Weight & Sinta Score 3 year \\
\hline 1 & $>=5000$ \\
0,75 & $>=2500$ \\
0,5 & $>=800$ \\
0,25 & $<800$ \\
\hline
\end{tabular}

The following is the collaboration performance measurement formula used:

$$
\text { Network_score }=\sum_{i=1}^{n} W_{i} . \text { Freq }_{i}
$$

Where Network_score $=$ Score Collaboration Network, $i$ is the $i$-th institution, $W i$ is the weight of institute $I$ and Freq $_{i}$ is the number of publications resulting from collaboration with the i-W institution calculated based on the sinta score for the last 3 years as shown in Table 1.

\begin{tabular}{|c|c|c|c|c|c|c|c|}
\hline Logo & Affiliation & $\begin{array}{l}3 \text { Year } \\
\text { Score }\end{array}$ & $\begin{array}{l}\text { All Year } \\
\text { Score }\end{array}$ & $\begin{array}{l}\text { All Year } \\
\text { Score v2 } \\
\uparrow\end{array}$ & $\begin{array}{l}\text { All Year } \\
\text { Score v2 } \\
\text { Productivity }\end{array}$ & $\begin{array}{c}3 \text { Year } \\
\text { Score v2 }\end{array}$ & $\begin{array}{c}3 \text { Year } \\
\text { Score v2 } \\
\text { Productivity }\end{array}$ \\
\hline 80 & $\begin{array}{l}\text { Universitas Indonesia } \\
\text { UlI Code : } 001002 \text { I }{ }_{\text {ID }} \\
\text { https://ui.ac.id }\end{array}$ & $\begin{array}{c}6,678 \\
\text { Since } \\
2017\end{array}$ & $\begin{array}{c}93,486 \\
\text { Overall } \\
\text { score }\end{array}$ & $\begin{array}{l}955,699 \\
\text { overall score }\end{array}$ & $\begin{array}{c}391 \\
\text { Devided Total } \\
\text { Lecturer }\end{array}$ & $\begin{array}{c}279,361 \\
\text { since } 2017\end{array}$ & $\begin{array}{c}114 \\
\text { Devided Total } \\
\text { Lecturer }\end{array}$ \\
\hline (8) & $\begin{array}{l}\text { Institut Teknologi Bandung } \\
\text { ITB | Code: } 002001 \mid \text { ID }_{\text {ID }} \\
\text { http://itb.ac.id }\end{array}$ & $\begin{array}{l}4,719 \\
\text { Since } \\
2017\end{array}$ & $\begin{array}{c}64,684 \\
\text { overall } \\
\text { score }\end{array}$ & $\begin{array}{l}899,133 \\
\text { overall Score }\end{array}$ & $\begin{array}{c}620 \\
\text { Devided Total } \\
\text { Lecturer }\end{array}$ & $\begin{array}{c}187,823 \\
\text { since } 2017\end{array}$ & $\begin{array}{l}129 \\
\text { Devided Toral } \\
\text { Lecturer }\end{array}$ \\
\hline 60. & $\begin{array}{l}\text { Universitas Gadjah Mada } \\
\text { UGMI Code : } 001001 \text { I } \boldsymbol{P}_{\text {ID }} \\
\text { https://ugm.ac.id }\end{array}$ & $\begin{array}{c}4,977 \\
\text { Since } \\
2017\end{array}$ & $\begin{array}{c}64,606 \\
\text { overall } \\
\text { score }\end{array}$ & $\begin{array}{l}808,541 \\
\text { Overall Score }\end{array}$ & $\begin{array}{l}280 \\
\text { Devided Toral } \\
\text { Lecturer }\end{array}$ & $\begin{array}{c}216,722 \\
\text { since } 2017\end{array}$ & $\begin{array}{l}75 \\
\text { Devided Total } \\
\text { Lecturer }\end{array}$ \\
\hline & $\begin{array}{l}\text { Institut Pertanian Bogor } \\
\text { IPB I Code : 002003| = } \\
\text { http://ipb.ac.id }\end{array}$ & $\begin{array}{c}2,968 \\
\text { Since } \\
2017\end{array}$ & $\begin{array}{c}60,704 \\
\text { overall } \\
\text { score }\end{array}$ & $\begin{array}{l}518,455 \\
\text { Overall Score }\end{array}$ & $\begin{array}{c}378 \\
\text { Devided Toral } \\
\text { Lecturer }\end{array}$ & $\begin{array}{l}117,823 \\
\text { since } 2017\end{array}$ & $\begin{array}{c}86 \\
\text { Devided Total } \\
\text { Lecturer }\end{array}$ \\
\hline $\int_{\text {LIPI }}^{4}$ & 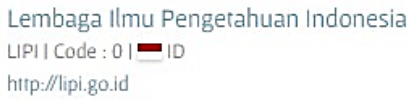 & $\begin{array}{c}1,361 \\
\text { Since } \\
2017\end{array}$ & $\begin{array}{c}38,640 \\
\text { Overall } \\
\text { score }\end{array}$ & $\begin{array}{l}364,181 \\
\text { Overall Score }\end{array}$ & $\begin{array}{c}0 \\
\text { Devided Toral } \\
\text { Lecturer }\end{array}$ & $\begin{array}{l}40,322 \\
\text { since } 2017\end{array}$ & $\begin{array}{c}0 \\
\text { Devided Total } \\
\text { Lecturer }\end{array}$ \\
\hline
\end{tabular}

Figure 2. SINTA Score for Affiliations (source: sinta.ristekbrin.go.id) 
Figure 2 is the list of affiliates indexed by SINTA, complete with the calculation of the affiliate score. Affiliation score is a composite calculation from various sources, especially the number of publications, quartile scopus, number of citations, indexation of journals whose formula we can see in the writings of Lukman et.al [17]. Furthermore, this score is used as the basis for cluster formation for the calculation of the higher education collaboration index.

\section{RESULTS AND DISCUSSION}

Each publication of an author's research results can be visualized to form a collaborative network as shown in Figure 3. For the purpose of calculating the collaboration index, what is next is calculated is collaboration with external universities and does not include collaborations with other authors from internal universities.

Author collaboration networks are a very important and basic part of forming a collaborative network map between institutions. Every author's cooperation with other affiliates will be calculated as part of the cooperation with other affiliates. The affiliate cluster that is used as a collaboration will be the multiplier weight for each collaboration.

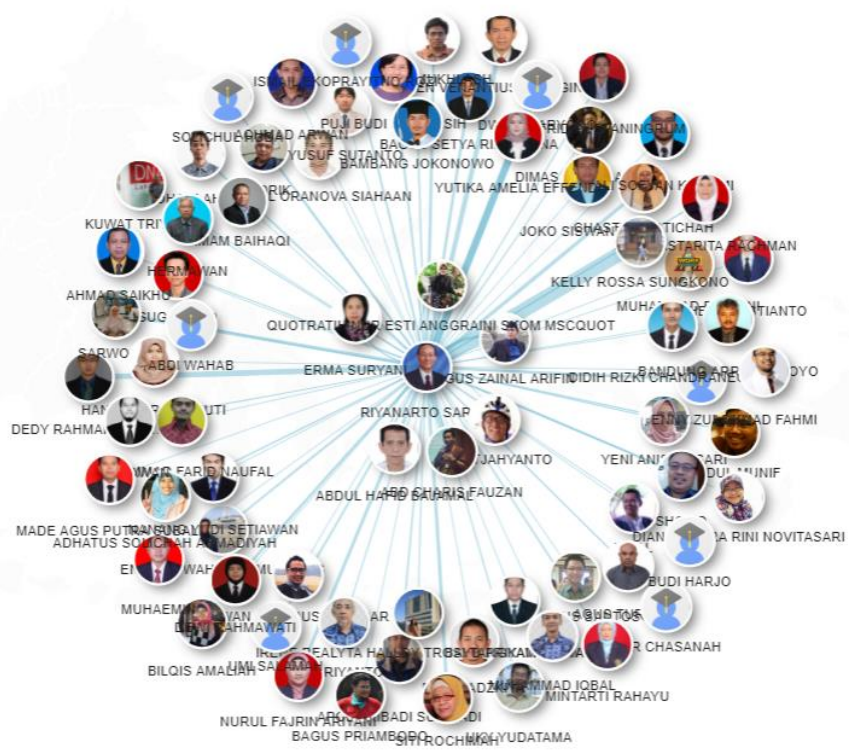

Fig 3. Author Collaboration Network

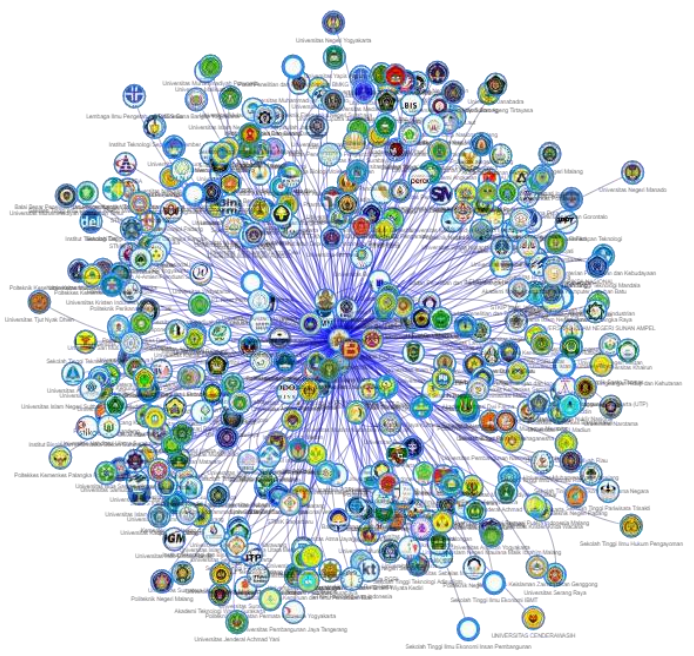

(a)

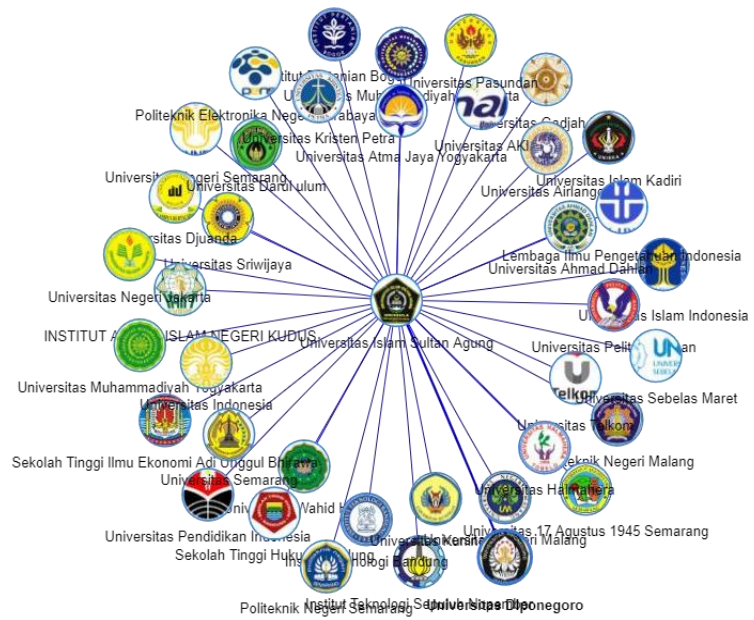

(b)

Fig 4. Affiliation Collaboration Network (a) Universitas Gadjah Mada (b) Universitas Islam Sultan Agung 


\subsection{Number of Collaboration}

The more research collaborations, the greater the impact of collaboration between institutions. Figure 4 (a) is an example of visualization of a collaboration network from UGM with a number of other universities based on collaborations conducted by authors from UGM, while Figure 4 (b) shows similar network for Universitas Islam Sultan Agung (UNISSULA). Each line between affiliates can represent more than one collaboration, so the number of collaborations can be higher from the image shown. Comparison of the two network images shows that UGM has a better score than UNISSULA because the number of collaborations is much larger.

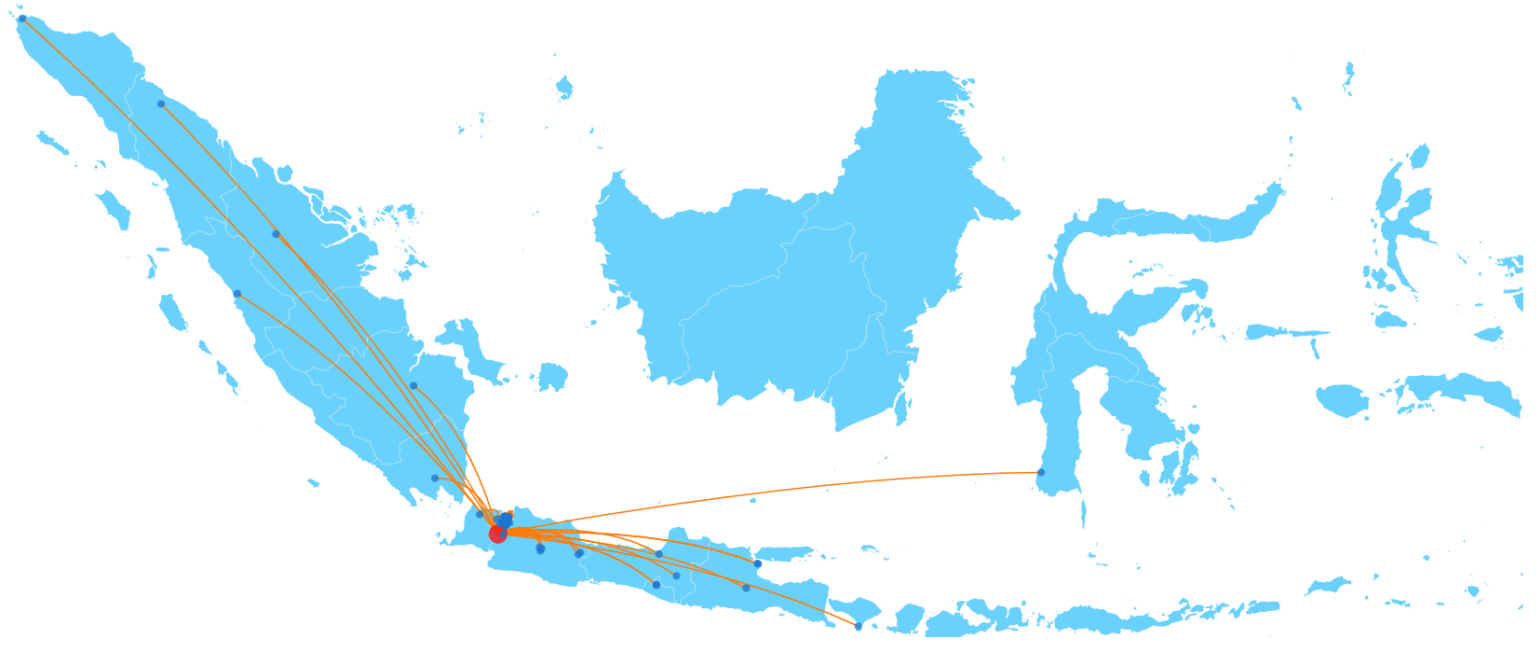

Fig. 5 Collaboration Map of Universitas Indonesia

Figure 5 shows a sample map of collaboration carried out by a higher education institution, Universitas Indonesia, which is represented by connections with 15 other university partners with the highest number of collaborations. This map makes it easy to analyze patterns of higher education cooperation by region.

\subsection{Frequency Analysis}

Research collaborations between higher education institutions can be analyzed based on cooperation maps and their frequency. Figure 6 is another way of visualizing research collaboration between universities when compared to Figure 5. This figure shows the frequency of collaboration carried out with the same university based on the size and size of the bubbles.

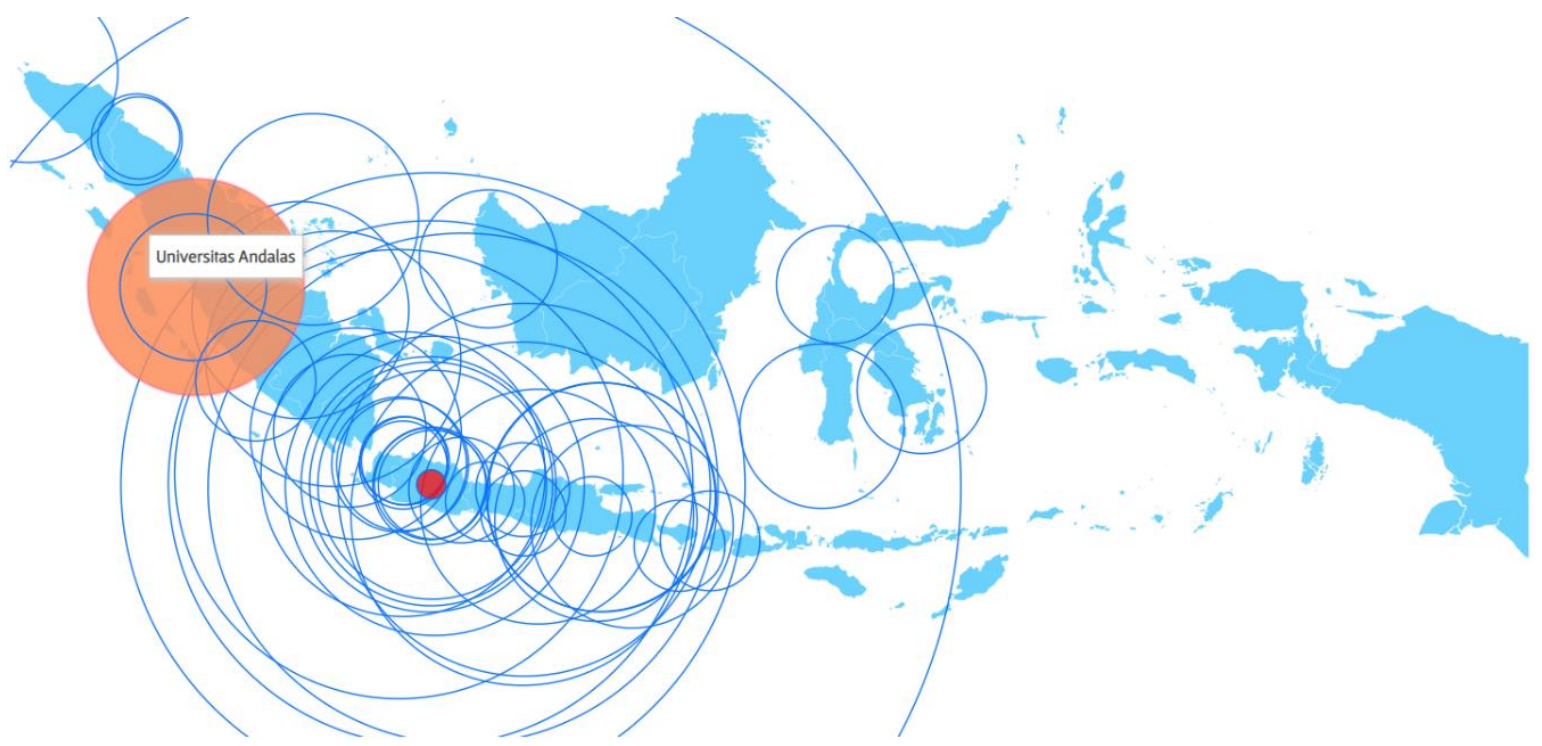

Fig. 6 Frequency Analysis of Research Collaboration by Institut Teknologi Bandung (ITB) 
Figure 7 is a detailed explanation of the frequency of collaboration carried out by ITB as an example of the case from Figure 6 where Andalas University is one of the large ITB collaboration partners. The bubble size of Telkom University is the biggest collaboration partner of ITB. Geographically, Telkom University is a city with ITB, namely the city of Bandung. The figure shows that the pattern of ITB collaboration partners is mostly at nearby universities, especially West Java and Jakarta, apart from other areas on the island of Java and Sumatra and Sulawesi.

\begin{tabular}{|c|c|c|}
\hline Logo & Affiliation & Collaborations \\
\hline & $\begin{array}{l}\text { Universitas Telkom } \\
\text { Tel-U I Code: } 041057 \text { I =ID } \\
\text { sig Authors }\end{array}$ & $\begin{array}{l}361 \\
\begin{array}{l}\text { Number of Publications from } \\
\text { Collabaration }\end{array}\end{array}$ \\
\hline & $\begin{array}{l}\text { Universitas Padjadjaran } \\
\text { UNPAD I Code : } 001007 \mid \text { | ID } \\
\text { Authors }\end{array}$ & $\begin{array}{l}213 \\
\begin{array}{l}\text { Number of Publications from } \\
\text { Collabaration }\end{array}\end{array}$ \\
\hline & $\begin{array}{l}\text { Universitas Pendidikan Indonesia } \\
\text { UPI | Code : } 001034 \text { | }=10 \\
\text { A Authors }\end{array}$ & $\begin{array}{l}179 \\
\begin{array}{c}\text { Number of Publications from } \\
\text { Collabaration }\end{array}\end{array}$ \\
\hline & $\begin{array}{l}\text { Lembaga IImu Pengetahuan Indonesia } \\
\text { LIPI | Code: } 01=\mid D \\
\text { Authors }\end{array}$ & $\begin{array}{l}174 \\
\begin{array}{c}\text { Number of Publications from } \\
\text { Collabaration }\end{array}\end{array}$ \\
\hline & $\begin{array}{l}\text { Universitas Indonesia } \\
\text { UII Code : } 001002 \text { I }=10 \\
\text { A Authors }\end{array}$ & $\begin{array}{c}153 \\
\begin{array}{c}\text { Number of Publications from } \\
\text { Collabaration }\end{array}\end{array}$ \\
\hline & $\begin{array}{l}\text { Universiras Diponegoro } \\
\text { UNDIP I Code : } 001008|=| D \\
\text { Authors }\end{array}$ & $\begin{array}{c}127 \\
\text { Number of Publications from } \\
\text { Collabaratian }\end{array}$ \\
\hline & $\begin{array}{l}\text { Universitas Gadjah Mada } \\
\text { UGMICode: } 001001 \text { I }=\text { ID } \\
\text { 열 Authors }\end{array}$ & $\begin{array}{c}117 \\
\begin{array}{l}\text { Number of Publications from } \\
\text { Collaboration }\end{array}\end{array}$ \\
\hline
\end{tabular}

Fig. 7 List of Collaboration frequency with other institusion

The frequency that occurs describes how often the collaboration is realized between universities and does not yet describe the quality of the collaboration. For the sake of fairness in measuring the cooperation score, it is necessary to weight each collaboration carried out based on the partner cluster.

Table 2. Collaboration Network Score of Institution

\begin{tabular}{cc}
\hline Institution & Collaboration Score \\
\hline Universitas Indonesia & 35,738 \\
Institut Teknologi Bandung & 48,656 \\
Universitas Gadjah Mada & 37,038 \\
Institute Pertanian Bogor & 20,950 \\
Universitas Airlangga & 13,931 \\
\hline
\end{tabular}

The results of the calculation of the score for research collaboration activities from the top 5 universities in SINTA can be seen in Table 2. Compared to other universities with low SINTA rankings, the average college with a high score also has a high collaboration score as well. This shows that research collaboration also improves the quality and productivity of higher education. However, higher education ranking based on SINTA score and based on collaboration score presents a difference, University of Indonesia which is ranked number 1 in SINTA has a smaller collaboration score than ITB which is number 2 in SINTA. When this paper was written, the highest collaboration score was carried by ITB with a total score of 48,656.

\subsection{Overall Indonesia Analysis of Collaboration Network}

Based on the research collaboration performance carried out by every university in Indonesia, it turns out that it has an uneven score. Figure 8 shows a map of the strength of collaboration for each region in Indonesia by province. On average, the island of Java conducts the most research collaborations but it turns out that Riau Province has the highest average research collaboration index in Indonesia. 


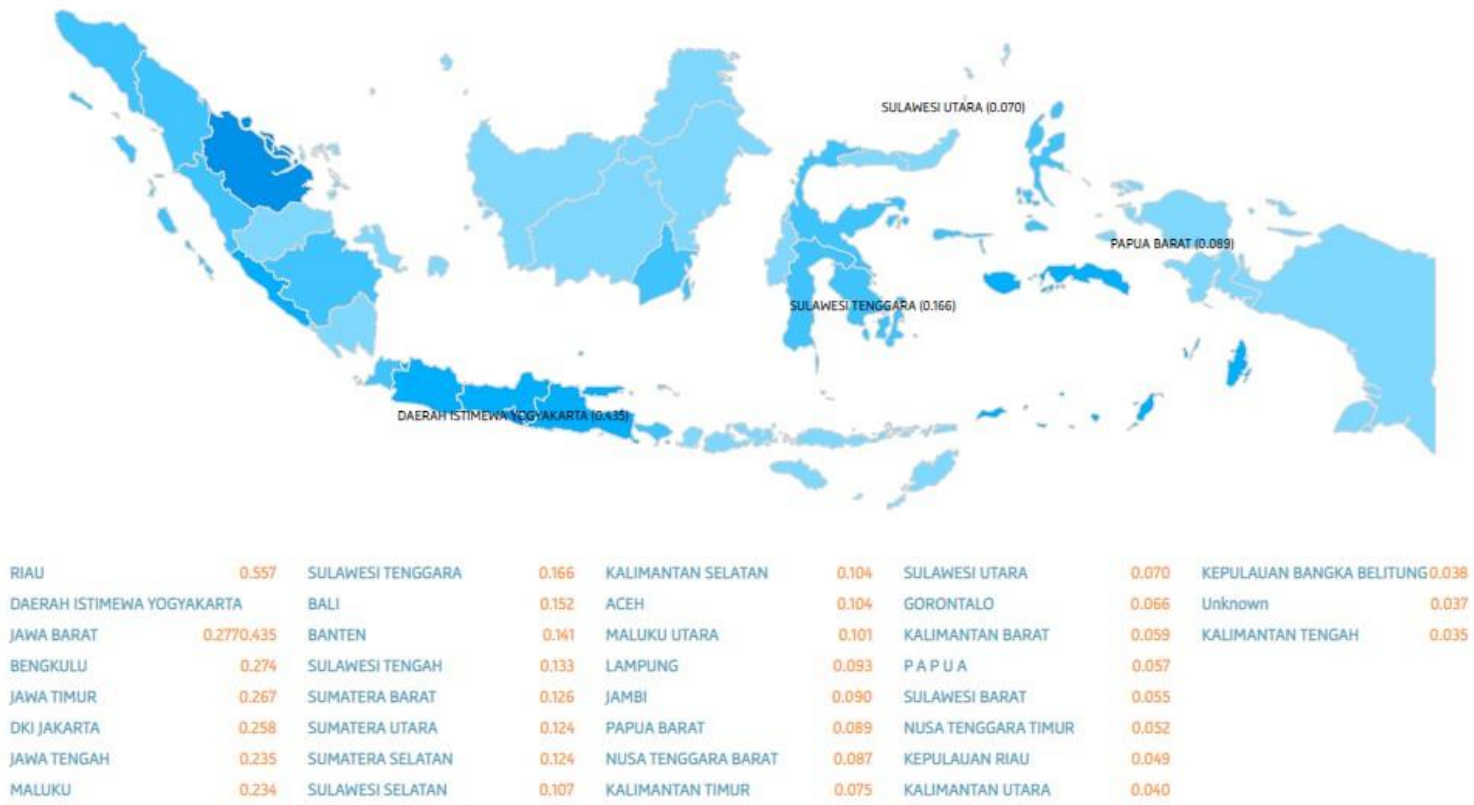

Figure 8. Research Collaboration Map of Universities based on Region

\section{CONCLUSION}

This research has proposed a research collaboration performance measurement formula based on reputable scientific publications. The formula proposed in this study is to consider the number and weighting based on the score of the institution in the previous year to calculate the new score for the performance of the scientific cooperation network. The results of the implementation show that Riau Province has the highest score of collaboration at the regional level, while the Bandung Institute of Technology has the highest score of 48.656 at the institutional level.

The results of the analysis of higher education scores based on SINTA show that the average SINTA score is high also has a high collaboration score as well. This shows that research collaboration also improves the quality and productivity of higher education. However, higher education rankings based on the SINTA score and based on the collaboration score do not always have the same ranking.

\section{ACKNOWLEDGMENTS}

This research was supported/partially supported by Ministry of Research and Technology and Higher Education Indonesia that funding under INSINAS scheme. We thank our colleagues from Universitas Islam Sultan Agung who provided insight and expertise that greatly assisted the research.

\section{REFERENCES}

[1] L. Aldieri, M. Kotsemir, and C. P. Vinci, "The impact of research collaboration on academic performance: An empirical analysis for some European countries," Socioecon. Plann. Sci., vol. 62, pp. 13-30, 2018.

[2] P. S. Nagpaul, "Exploring a pseudo-regression model of transnational cooperation in science," Scientometrics, vol. 56, no. 3, pp. 403-416, 2003.

[3] M. Paier and T. Scherngell, "Determinants of collaboration in European R\&D networks: empirical evidence from a discrete choice model," Ind. Innov., vol. 18, no. 1, pp. 89-104, 2011.

[4] L. Kuld, "A local idea space: the value of personal and thematic proximity in academic research," Trinity College Dublin, Department of Economics, 2017.

[5] D. J. Stein et al., "A brain-behaviour initiative for South Africa: the time is right," Metab. Brain Dis., vol. 21, no. 2-3, pp. 266-271, 2006.

[6] M. Graue, M. M. Iversen, Á. K. Sigurdardottir, V. Zoffmann, B. Smide, and J. Leksell, "Diabetes research reported by nurses in Nordic countries," Eur. Diabetes Nurs., vol. 10, no. 2, pp. 46-51, 2013.

[7] H. Kodama, K. Watatani, and S. Sengoku, "Competency-based assessment of academic interdisciplinary research and implication to university management," Res. Eval., vol. 22, no. 2, pp. 93-104, 2013. 
[8] A. Riahi, H. Siamian, A. Zareh, R. A. Navaei, M. R. Haghshenas, and I. Sari, "Quantitative Evaluation of Scientific Productions in Iran in Immunology and Microbiology Indexed in Scopus Database."

[9] W. M. Sweileh, N. Y. Shraim, H. Z. Sa'ed, and S. W. Al-Jabi, "Worldwide research productivity on tramadol: a bibliometric analysis," Springerplus, vol. 5, no. 1, p. 1108, 2016.

[10] C. Beaudry and S. Allaoui, "Impact of research funding on nanobiotechnology scientific production: Does concentration in a few universities make sense?," in 2011 Atlanta Conference on Science and Innovation Policy, 2011, pp. 1-28.

[11] F. Lissoni, J. Mairesse, F. Montobbio, and M. Pezzoni, "Scientific productivity and academic promotion: a study on French and Italian physicists," Ind. Corp. Chang., vol. 20, no. 1, pp. 253-294, 2011.

[12] L. G. Zucker and M. R. Darby, "Capturing technological opportunity via Japan's star scientists: Evidence from Japanese firms' biotech patents and products," J. Technol. Transf., vol. 26, no. 1-2, pp. 37-58, 2001.

[13] J. P. Elhorst, and Katarina Zigova. "Competition in research activity among economic departments: Evidence by negative spatial autocorrelation." Geographical Analysis vol. 46, no. 2 pp. 104-125, 2014.

[14] R. Chakravarty and D. Madaan, "SCOPUS reflected study of selected research and higher education institutions (HEIs) of Chandigarh: a city of education and research," Libr. Hi Tech News, 2016.

[15] M. O. Obamba and J. K. Mwema, "Symmetry and asymmetry: New contours, paradigms, and politics in African academic partnerships," High. Educ. Policy, vol. 22, no. 3, pp. 349-371, 2009.

[16] Z. Chinchilla-Rodríguez, V. Larivière, R. Costas, N. Robinson-García, and C. R. Sugimoto, "Building ties across countries: international collaboration, field specialization, and global leadership," 2018.

[17] L. Lukman et al., "Proposal of the S-score for measuring the performance of researchers, institutions, and journals in Indonesia," Sci. Ed., vol. 5, no. 2, pp. 135-141, 2018, doi: https://doi.org/10.6087/kcse.138. 